Witold Starnawski

Uniwersytet Kardynała Stefana Wyszyńskiego

\title{
CZYM JEST REALIZM W PEDAGOGII OSOBY?
}

\author{
What is realism in pedagogy of the person?
}

\begin{abstract}
S u m mary: This article presents reflections on the realistic foundations of pedagogy. The main theses put forward are: 1. Realism as a philosophical idea is not the aim of pedagogy, but rather a fundamental condition thereof; 2. A realistic attitude also entails the confirmation of the subjectivity of man; 3 . Subjectivity refers firstly to the realm of feelings and sensations, secondly, to the realm of consciousness and cognitive acts, and thirdly and most importantly, to the realm of spiritual life: acts of intellect and will; 4. The category of truth is more effective and deeper in pedagogy than the category of realism; 5 . There are many interesting and important questions to consider in that subject, for example: the significance of "non-real" matters for upbringing (such as future projects, dreams, and fantasies), what it means "to love in reality" (or in truth), or the question of "selfless engagement".
\end{abstract}

Keywords : realism, realistic attitude, truth, subjectivity, exemplar, personalism

Problem realizmu pojawia się $\mathrm{w}$ pedagogii niezbyt często $\mathrm{i}$ wbrew pozorom nie jest on tylko przeniesiony $\mathrm{z}$ „zewnątrz”, z rozważań filozoficznych, ma również swoje specyficzne pedagogiczne znaczenie. Dotyka ważnych spraw wychowawczych, o których niewiele mówi określenie „wychowanie realistyczne”. Potrzeba tu większej precyzji, która dookreśliłaby sens używanych pojęć, a przede wszystkim potrzeba pedagogicznego rozeznania, które pozwoliłoby wniknąć w osobowe, wychowawcze i praktyczne ich znaczenie. W aspekcie filozoficznym odwołujemy się do metafizycznego i poznawczego znaczenia realizmu1, a więc do stanowiska, które przyjmuje realne, obiektywne, niezależne od świadomości - nie pozorne, wymyślone, urojone czy możliwe - istnienie rzeczywistości (bytów) oraz uznaje jej poznawalność. $\mathrm{W}$ aspekcie osobowym i pedagogicznym jest to najpierw właściwe odczytanie (rozpoznanie) rzeczywistości, „przylgnięcie do niej”, następnie diagnoza odpowiadająca prawdziwemu dobru osoby, wreszcie - wybranie właściwej drogi rozwoju, korygowanie jej, naprawienie błędów.

\footnotetext{
${ }^{1}$ Por. Mały Stownik terminów ipojęć filozoficznych, oprac. Antoni Podsiad, Zbigniew Więckowski (Warszawa: Instytut Wydawniczy Pax 1983), 329.
} 
Można wskazać trzy zagadnienia, które moim zdaniem pogłębiają w aspekcie wychowawczym rozumienie realizmu. Po pierwsze, jest to postulat „poszerzenia” realistycznego ujęcia o sferę subiektywności i nie tyle chodzi o sferę przeżyć oraz uczuć, ile o kwestię „wewnętrznego” charakteru duchowości człowieka. Po drugie, jest to kwestia prawdy - to nieco inne ujęcie tego samego problemu, bardziej efektywne z punktu widzenia pedagogii (pedagogiki). Wreszcie, po trzecie, warto zauważyć, że w pedagogii (pedagogice) realizm winien dotyczyć w jakiejś mierze także tego, co jest wzorem i ,ideałem”, ma więc charakter normatywny, ponieważ wskazuje działania „na miarę osoby” - za realistyczne w koncepcji personalistycznej uznawane byłyby takie wzory (i w konsekwencji aktualizujące je działania), które prowadziłyby byt osobowy do pełni, do doskonałości wyznaczonej na jego miarę.

Kiedy używam określenia „pedagogia osoby” to mam na myśli poddane refleksji działania wychowawcze lub praktyczną (nastawioną na działanie) wychowawczą refleksję. Wprawdzie rozumienie realizmu z perspektywy pedagogicznej jest nieco inne niż filozoficzne, to nie znaczy, że jest z nim niezgodne (tym bardziej - sprzeczne). Chodzi natomiast o to, aby zwrócić uwagę na to, co wykracza poza aspekt filozoficzny, dopełnia go, a w pewnym nawet sensie stanowi dodatkowe źródło potwierdzające „doświadczalnie” wartość realizmu w odniesieniu do osoby.

\section{Realizm subiektywności}

Potrzeba czy wręcz konieczność dowartościowania subiektywnej sfery człowieka opiera się na przekonaniu, że realizm nie jest poglądem, doktryną czy ideologią, lecz postawą poznawczą polegającą na „wiernym odczytaniu rzeczywistości”. W przypadku osoby wymaga ona uznania realności, „obiektywności” tego, co subiektywne, podmiotowe, wewnętrzności bycia człowieka. W artykule „Podmiotowość $\mathrm{i}$ «to, co nieredukowalne» w człowieku” Karol Wojtyła stwierdza: „Chodzi bowiem nie tylko o metafizyczną obiektywizację człowieka jako podmiotu działającego, czyli sprawcy swoich czynów, ale chodzi o ukazanie osoby jako podmiotu przeżywającego swoje czyny, swoje doznania, a w tym wszystkim swoją podmiotowość" „[...] nie skazujemy się na subiektywizm ujęcia, z a b e z p i e c z a m y natomiast autentyczną subiektywność człowieka, tzn. jego osobową podmiotowość, wrealistycznej interpretacji jego bytu"s. Wojtyła nie zatrzymuje się na tym stwierdzeniu, idzie dalej, stawiając postulat dotyczący traktowania tego, co nieredukowalne, jedyne, niepowtarzalne: ,[...] t r z e b a m u dawać jakby pewną przewagę w myśleniu oczłowieku, w teorii

\footnotetext{
2 „Podmiotowość i „«to co nieredukowalne» w człowieku”, w: Karol Wojtyła, Osoba i czyn oraz inne studia antropologiczne (Lublin: TN KUL 1994), 439.

${ }^{3}$ Tamże.
} 
i w praktyce"4. Mamy do czynienia już nie z dowartościowaniem, ale wręcz z nadwartościowaniem sfery subiektywnej (wewnętrznej), dlatego, że chodzi o to „co w człowieku niewidzialne, co całkowicie wewnętrzne, a p r ze z c o k a ż d y c złowiek jest jakby naocznym świadkiem siebie samego, swojego człowieczeństwa i swojej osoby"5.

Uzasadnienie to można również wyrazić w języku bardziej obiektywistycznym. Wyższa wartość tego, co wewnętrzne w człowieku, nie wynika ani z zamiaru podkreślenia jego jednostkowości, ani z chęci dowartościowania subiektywnych przeżyć czy uczuć, wynika natomiast z odsłonięcia oczywistego wydawałoby się faktu, że akty duchowe człowieka (jego życie duchowe), na które składają się akty poznawania (i uznawania) prawdy, świadomie przyjęte motywy, decyzje, akty wartościowania, przebaczenia, uznania winy, podjęcia odpowiedzialności - są aktami wewnętrznymi. Ludzka duchowość w takim znaczeniu ma zatem charakter subiektywny, ale równocześnie - i to jest aspekt o którym zbyt często się zapomina - jest/powinna być od wewnątrz związana prawdą. Patrzeć obiektywnie, realistycznie na człowieka to znaczy przyznawać, że istnieje w nim sfera subiektywna. Ponadto uznać, że jego „wnętrze” jest ważniejsze niż „to, co zewnętrzne”, dlatego, że „wnętrze” oznacza w tym przypadku „to, co duchowe”.

Przyjęcie takiej perspektywy przynosi wiele trudności metodologicznych i poznawczych, poczynając od tego, że tylko w części „to, co wewnętrzne” daje się obiektywizować i adekwatnie ująć w języku pojęciowym, gdyż w jakiejś mierze jest to wiedza dotycząca tego, co jednostkowe, zindywidualizowane. Nie wydaje się jednak, aby te - przyznajmy, że poważne - przeszkody mogły stanowić usprawiedliwienie dla niezauważania i omijania tego problemu. Realizm, pragnienie poznawania prawdy, szacunek dla niej nakazują wtym przypadku przyjęcie realizm u s u b i e k t y w n o ś c i - wewnętrzności człowieka.

\section{Prawda wewnętrznym fundamentem osoby}

Metafizyczny i teoriopoznawczy realizm jest warunkiem sensownego uprawiania jakiejkolwiek refleksji, która chce „trzymać się bytu”, a nie stać się urojeniem czy fantazją. Z tej perspektywy realizm jest podstawą wszelkiego racjonalnego poznawania, a jego odrzucenie dyskwalifikuje badacza, który chciałby zajmować się jakimkolwiek „przedmiotem” świata rzeczywistego. Warto zwrócić uwagę, że ten konieczny od strony teoretycznej postulat zyskuje jeszcze inny wymiar w teorii osoby, w konsekwencji również w pedagogii (pedagogice). Odsłania zdolność poznawania prawdy jako ważny czynnik aktualizowania tożsamości osoby oraz realizacji jej zdolności do transcendencji.

\footnotetext{
${ }^{4}$ Tamże, 440.

5 Tamże, 440-441.
} 
K. Wojtyła, analizując w Osobie i czynie akty poznania i woli, wskazuje, że wewnętrznie są one uksztaltowane przez odniesienie do prawdy ${ }^{6}$. W aktach poznania chodzi o to, co autor nazywa transcendencja poziomą; szczególnie znaczące jest wewnętrzne uzależnienie aktów woli. „Odniesienie do prawdy” nie jest tym samym co relacja do przedmiotów chcenia. „Relacja do prawdy nie wyczerpuje się w strukturze chcenia jako aktu intencjonalnego, stanowi natomiast o zakorzenieniu tegoż aktu w osobie"7. Wskazuje ono na zależność od osoby, która jest „zależnością w prawdzie”. Autor Osoby i czynu stwierdza wprost, że to, co stanowi o osobie, co wyróżnia ją spośród świata rzeczy, a więc transcendencja osoby w czynie „wynika z relacji do prawdy". Moment prawdy najlepiej - zdaniem K. Wojtyły - rozgranicza to, co człowiek czyni od tego, co się w nim tylko dzieje, tym samym więc aktualizuje tożsamość człowieka jako osoby. Analiza ta dokonana jest od strony podmiotu, ale to nie powinno przesłaniać zasadniczej tezy, że chodzi o prawdę obiektywną, transcendentną wobec poznającego. Z tej perspektywy można lepiej zrozumieć, dlaczego postawa realistyczna, nakierowana na rzeczywistość, na prawdę, jest tym, co odpowiada osobie, spełnia ją. Jest więc dla niej nie tylko punktem wyjścia, ale również - w pewnym sensie - punktem dojścia, w takim znaczeniu, że tylko poprzez przyjęcie i realizację prawdy osoba staje się sobą. W ten sposób formuła, że człowiek żyje dzięki prawdzie, zyskuje jeszcze jedno znaczenie. Pozwala lepiej rozumieć postulaty wychowawcze, które mówią o potrzebie/konieczności poszukiwania prawdy, przyjmowania i realizowania jej (życia według niej).

\section{Realizm wzorów (ideałów)}

Nie można rozpatrywać wychowania, pomijając proces dążenia do celu, do realizacji wzoru. Doskonałość osoby jako cel wychowania jest tym „co-jeszcze-nie-jest”, należy do przyszłości, nie zawiera się w stanie aktualnym. Jakie znaczenie miałaby w tym przypadku kategoria realizmu? W jakim sensie wzór (ideał) miałby być „wierny rzeczywistości”, co by to mogło znaczyć? Na pewno przecież nie chodzi tu o znaczenie potoczne „realizmu”, które wskazuje na jakąś przyziemność ideałów, w którym chodzi o „sprowadzenie ich na ziemię”, a więc o „realizm”, który każe być praktycznym, ostrożnym, wyrachowanym. Zapewne z perspektywy filozofii tomistycznej pomocne byłoby przywołanie kategorii przyczyny wzorczej. Czy jednak byłaby to kategoria wystarczająca do rozwiązania pojawiających się tu problemów? Z wychowawczego punktu widzenia można wskazać ich wiele. Na przykład:

1) w jakim stopniu wzory (ideały) są wewnętrzne, a w jakim zewnętrzne wobec podmiotu;

2) czy on sam je tworzy, czy raczej są mu „dane”;

\footnotetext{
${ }^{6}$ Wojtyła, Osoba, 164, 181-183.

${ }^{7}$ Tamże, 182.

${ }^{8}$ Tamże, 185. W innym miejscu: „Prawda stanowi rację bytu ludzkiego poznania, równocześnie zaś jest ona podstawą transcendencji osoby w działaniu. Czyn bowiem jest sobą poprzez moment prawdy - mianowicie prawdy o dobru - który to moment nadaje mu kształt autentycznego actus personae”. (tamże, 189).
} 
3) czy są ogólne, czy raczej konkretne, „skierowane” do tego oto konkretnego podmiotu;

4) w jakiej mierze mogą oddziaływać na rzeczywistość; przecież wzory (ideały) powinny mieć wystarczającą „moc sprawczą”, aby mogły motywować wychowanka do działania;

5) w jakim stopniu są osiągalne (czy można osiągnąć postulowaną przez nie doskonałość)?

Z wychowawczego i praktycznego punktu widzenia są to problemy ważne, wydaje się, że sama metafizyka nie potrafi ich rozwiązać, potrzebna jest refleksja sięgająca do wewnętrznej rzeczywistości osoby oraz wykorzystanie zasobów doświadczenia wychowania9. Moim zdaniem należałoby uwzględnić i podkreślić normatywny charakter kategorii „natura”, a w jeszcze większym stopniu - „osoba”. Warto przypominać, że rozumność i wolność są „własnościami”, które każdy człowiek „ma” (w sposób potencjalny, co nie znaczy, że potencjalnie jest człowiekiem), ale jednocześnie powinien je aktualizować. Podobnie jest w przypadku drugiej kategorii. Osobą się „jest” w aspekcie ontycznym, równocześnie „stając się” nią poprzez używanie rozumu i spełnianie czynów. Dzięki temu - w terminologii Wojtyły człowiek ma szansę spełnić siebie, „stać się sobą”. Realizm w tym przypadku oznaczałby potwierdzenie, że każdemu człowiekowi przysługuje kategoria natury (osoby - co współcześnie bywa niekiedy kwestionowane) oraz że jest to kategoria, która wymaga aktualizacji, dopełnienia. Warto w związku z tym podkreślać, że wzór nie musi być czymś, co istnieje „idealnie”, lecz można uznać, że ma podstawy egzystencjalne w naturze człowieka (bycie osoby), w pewien więc sposób „jest w nim" ${ }^{10}$. Dążenie do realizacji wzoru byłoby więc nie tyle twórczością, co aktualizacją tego, co człowiekowi „zadane”. A ponieważ to, co „zadane”, opiera się na tym, co „dane”, nie może więc być dowolne. Realistyczna sprawczość człowieka oznaczałaby, że powinien on brać pod uwagę to, kim jest, że ma ciało, jakie ma zdolności, w którym „miejscu” się znajduje, kto żyje wokół niego. Nie chodzi wyłącznie o okoliczności i wyznaczenie konkretnych „ram” działania, lecz również o zobowiązania oraz powinności wynikające ze wszystkich okoliczności życia, a przede wszystkim z faktu współbycia z innymi, ze spotkania konkretnych osób. Człowiek nie działa bowiem $\mathrm{w}$ pustej przestrzeni, lecz wobec innych, z innymi i dla innych. Realistyczne w tym przypadku byłoby podjęcie takich działań, które przeciwdziałają złu i destrukcji a realizują dobro, pomagają ko nkretnym ludziom stać się dobrymi (doskonałymi), zaradzają ich potrzebom, wydobywają, ukazują (aktualizują) piękno i stn i eją c e go świata i ludzi. Twórczość człowieka w zakresie doskonalenia siebie polegałaby więc na odczytaniu dobra oraz piękna i sposobu ich realizacji w nim samym, a także w tym, co go otacza i spotyka, nie zaś na tym, by człowiek realizował

\footnotetext{
${ }^{9}$ Na temat szerokiego rozumienia terminu „doświadczenie wychowania” zob. w pracy: Witold Starnawski, Prawda jako zasada wychowania (Warszawa: Wydawnictwo UKSW 2008), 105-194.

${ }^{10}$ Metafizycznego uzasadnienia należałoby, moim zdaniem, szukać także w rozwinięciu Tomaszowej teorii transcendentaliów - przede wszystkim dobra oraz piękna - i ukazaniu ich aspektu realistycznego, a także aksjologicznego.
} 
to, co w dowolny sposób „wymyśli”, „wymarzy”, „zaprojektuje” niezależnie, bez związku z istniejącą rzeczywistością.

Czy istnieje tu niebezpieczeństwo tworzenia „idealistycznych systemów”, utopii, ideologii oderwanych od rzeczywistości? Zapewne tak, ale należy zwrócić uwagę, że ten świat dóbr (w języku bardziej współczesnym - świat wartości) jest związany ze światem realnym, przede wszystkim z realnym, konkretnym bytem człowieka-osoby. Lekarstwem i zabezpieczeniem byłaby w tym przypadku realizacja postulatów realizmu, a jeszcze lepiej - czujność oraz wytrwałość w dążeniu do pełnej prawdy o rzeczywistości, a także o osobie.

Należy zwrócić uwagę na jeszcze jeden aspekt. W wychowaniu ważną rolę spełnia zasada naśladowania, odwołująca się do wzorców osobowych. Wydaje się, że zasada ta będzie miała swoją „siłę” zdolną motywować działania osoby wówczas, gdy osoba-wzór będzie kimś realnym. K. Wojtyła podejmuje to zagadnienie, dyskutując z M. Schelerem w swojej rozprawie habilitacyjnej ${ }^{11}$. Pisze: „[...] ze względu na to, że etyka chrześcijańska zakłada realną moralną doskonałość osoby i osób, że o nią zabiega, nazywamy ten ideał doskonałości moralnej w niej zawarty ideałem realnym" ${ }^{\prime 2}$. Wojtyła zwraca uwagę, że dla Schelera przedmiotem naśladowania nie jest „realna doskonałość moralna osoby mistrza, lecz to, co nazywa on «idealną istotą wartościową»"13. Można zatem pytać, jak to, co istnieje nie-realnie (w tym przypadku intencjonalnie), może mieć realną siłę oddziaływania? Nie należy zapominać, że odkrycie realności doskonałego wzoru-osoby ma charakter religijny. Jest nim Jezus Chrystus - Bóg i Człowiek. Czy zatem warto posługiwać się tą argumentacją w płaszczyźnie naturalnej, nie religijnej? Czy pedagogika nienawiązująca do inspiracji religijnej ma szansę odkryć realizm wzoru-osoby nieposiadający charakteru boskiego ${ }^{14}$ ?

Nie jest to łatwe zagadnienie, ale można je próbować rozwiązać, wychodząc od przeciwnego założenia. Człowiek w swoim doświadczeniu nie ma do czynienia z absolutnym, nieskończonym dobrem i pięknem, tylko z dobrem i pięknem cząstkowym, ułomnym, a przecież nie wynika z tego, że nie wie, czym ono jest, że je odrzuca dlatego, że jest cząstkowe i niepełne, że nie potrafi rozpoznać czy odróżnić dobra oraz piękna od zła i brzydoty. Przy takim rozumieniu osoba, którą się naśladuje, nie musi być w stopniu nieskończonym doskonała, wystarczy, że jest „realnie doskonała” w pewnym aspekcie, w tym właśnie, który jest godny naśladowania ${ }^{15}$.

${ }^{11}$ Karol Wojtyła, Ocena możliwości zbudowania etyki chrześcijańskiej przy zalożeniach systemu Maksa Schelera (Lublin: TN KUL 1959), 29-39.

${ }^{12}$ Tamże, 32.

${ }^{13}$ Tamże, 37.

${ }^{14}$ Równocześnie trudno nie zauważyć, że chrześcijańska inspiracja religijna ma z tego powodu duże znaczenie w pedagogice, o ile oczywiście wychowawca, a zwłaszcza wychowanek, ją podzielają.

15 Pomocne mogą tu być rozważania Władysława Tatarkiewicza zjego rozprawki $O$ doskonatości (Warszawa: PWN 1976). 


\section{Aspekt praktyczny}

Powyższe rozważania mają ważny aspekt praktyczny. Kiedy mówi się o problemie prawdy w wychowaniu, zwykle ma się na myśli kwestię prawdomówności czy kłamstwa. Nie umniejszając znaczenia tej kwestii, chyba najtrudniejszych z etycznego punktu widzenia, trzeba podkreślać, że chodzi o bardziej podstawowy wymiar prawdy, pozwalający zrozumieć podstawy bytu osoby i jej specyfikę. Chodzi o to, że w pedagogii (pedagogice) posługiwanie się kategorią prawdy bardziej niż kryterium realizmu pozwala lepiej i głębiej (zatem w sposób bardziej realistyczny) spojrzeć na wychowanie, a więc na to wszystko, co wiąże się z udzielaniem wsparcia w procesie doskonalenia się osoby.

Wychowanie może być rozpatrywane w wielu aspektach, spośród których do najważniejszych należą perspektywa wychowawcy oraz wychowanka, trzeba je również ujmować jako relację i współzależność, której przebiegu czy rezultatu nie można do końca określić i przewidzieć, jest bowiem (powinna być) spotkaniem, a także dialogiem dwóch wolnych podmiotów - osób. Można (a nawet należy) patrzeć na wychowanie także w szerokim aspekcie, który obejmuje wszelkie rzeczywiste wpływy na jednostkę dokonujące się głównie w sposób nieświadomy, niezamierzony, a określany przez Stefana Kunowskiego jako środowisko wychowawcze ${ }^{16}$. Właściwy jednak proces wychowania dokonuje się w środowisku, które S. Kunowski nazywa pedagogicznym, podkreślając, że mowa wówczas o działaniach świadomych i celowych ${ }^{17}$.

Trzeba jednak dopowiedzieć, że nie chodzi tylko o działania wychowawcy, lecz również o postawy wychowanka. Wychowanie powinno więc zmierzać do tego, aby „obudzić” w nim świadomość własnej tożsamości, poczucie sprawczości i gotowość do podjęcia odpowiedzialności za proces samodoskonalenia. K. Wojtyła zwraca na to uwagę w Osobie i czynie, podkreślając znaczenie takich kategorii jak samozależność, transcendencja, samostanowienie, a nade wszystko wprowadzając określenie „personalistyczna wartość czynu”. Wartość ta „tkwi w samym spełnianiu czynu przez osobę, w samym fakcie, że «człowiek działa» w sposób sobie właściwy"18. To „działanie” właściwe człowiekowi polega na tym przede wszystkim, że tworzy sam siebie, a więc panuje nad sobą, stanowi o sobie, odpowiada za siebie. Zadaniem wychowawcy powinno być „obudzenie” wwychowanku świadomości odpowiedzialności za siebie i rozbudzenie w nim gotowości kierowania własnym rozwojem, a także przekonanie go, że nie jest to rozwój dowolny, powinien bowiem

${ }^{16}$ Zob. Stefan Kunowski, Podstawy wspótczesnej pedagogiki (Warszawa: Wydawnictwo Salezjańskie 2000), 229-230.

${ }^{17}$ Zob. tamże. Sprawa wydaje się bardziej skomplikowana, gdyż także we wpływach, które S. Kunowski przypisuje środowisku wychowawczemu, występują działania świadome i celowe nakierowane na osobę, tyle, że na proces wychowania oddziaływają one pośrednio. Wychowawczy aspekt kultury, tradycji, zwyczajów, a więc tego, co oddziaływa przez znaki, symbole i język, wymagałby odrębnych rozważań.

${ }^{18}$ Wojtyła, Osoba i czyn, 304-306. 
kierować się kryteriami służącymi osobie, gdyż może doprowadzić do spełnienia, ale także do samozniszczenia. Potrzeba, aby wychowawca dał impuls woli wychowankowi, by „chciał chcieć”, aby nie tkwił w stanie bierności, lecz był świadomym siebie podmiotem, sprawcą czynów ${ }^{19}$. W tym miejscu pojawia się kwestia realizmu i prawdy - chodzi o rozpoznanie, kim człowiek jest (kim być powinien - jaka jest jego miara, w jakim jest miejscu swego rozwoju) oraz czy jest gotowy działać zgodnie z prawdą o sobie.

Z perspektywy wychowawcy jest to kwestia właściwej diagnozy, a potem umiejętności postawienia wymagań oraz wsparcia w ich realizacji. Prawda o osobie, nie ogólna, lecz konkretna, dotycząca wychowanka, powinna być w centrum działań wychowawcy i trzeba dodać, że oznacza to trudną życzliwość, bowiem powinien być on gotowy na to, że spotka się z niezrozumieniem, brakiem wdzięczności, a nawet odrzuceniem.

Jednym z najtrudniejszych dla wychowawcy zadań pozostaje nauczyć wychowanka „kochać prawdę” i to bez względu na trudności; wiemy przecież, że prawda jest wymagająca, a bywa gorzka i bolesna. Człowiek ma więc pokusę, aby od niej uciekać, tkwić w pełnym złudzeń świecie, a przede wszystkim unikać czy odsuwać prawdę o sobie, swoich słabościach, potknięciach, winach.

Od strony wychowanka „pokochać prawdę” (a tym samym rzeczywistość) oznacza przyjąć postawę otwartości, a więc uznać, że prawda o świecie, innych ludziach, sobie samym jest niezależna od człowieka, transcendentna i w tym znaczeniu obiektywna. Jak jednak kogoś nakłonić, aby przyjął taką postawę? Nie można przecież przymusić kogoś, aby „pokochał prawdę”, by odkrył radość w rzeczach trudnych dla niego, niekiedy bolesnych i nieprzyjemnych. Wydaje się, że w tym przypadku metafizyka realistyczna może przyjść z pomocą, przypominając, że każdy byt jest dobry (dobro jako transcendentalna „własność” bytu), że najważniejszym „dobrem” bytu jest jego istnienie. Niedaleko od takiej postawy teoretycznej do akceptacji i zachwytu świętego Franciszka z Asyżu wobec wszystkiego, co istnieje. To, czy ktoś wybierze drogę świętego Tomasza, świętego Franciszka czy jakąś inną jest mniej ważne, ważniejsza jest akceptacja rzeczywistości danej człowiekowi, w której przyszło mu żyć, poszukiwanie prawdy o niej, przyjęcie jej i gotowość trwania przy niej.

\section{Podsumowanie}

Problem realizmu w pedagogii (pedagogice) można przedstawić $\mathrm{w}$ formie tez stanowiących ramy jednolitego stanowiska, stanowią one zarazem propozycję otwartą na krytykę i zaproszenie do dyskusji.

\footnotetext{
${ }^{19}$ Nie dość podkreślania, że nie chodzi tu o jakiekolwiek działanie zewnętrzne, lecz o czyn, w tym jego wewnętrzny aspekt, jakim jest stanowienie o sobie.
} 
1. Realizm nie jest celem działań wychowawczych, jest ich niezbędnym warunkiem, celem jest pomoc w doskonaleniu osoby; jest to warunek konieczny, niepodważalny, ale dla pedagogiki niewystarczający.

2. Realizm nie jest tylko nastawieniem poznawczym czy poglądem, to w gruncie rzeczy postawa: wyraża stosunek do świata (do rzeczywistości, do innych, do siebie samego).

3. Realizm w przypadku osoby oznacza przyjęcie jej subiektywności, wewnętrzności jej bytu.

4. Świat subiektywny (wewnętrzny) to po pierwsze, ale nie najważniejsze - świat wrażeń, nastrojów, emocji, uczuć; po drugie - świat myśli i poznania: przeżycia poznawcze, świadomość, samoświadomość, subiektywny aspekt aktów poznawczych itp.; po trzecie - świat duchowy w sensie właściwym, a więc osobowe akty poznawcze: sądy, uznawanie (przyjmowanie) prawdy oraz akty woli.

5. Kategoria prawdy wydaje się w pedagogii (pedagogice) bardziej efektywna niż kryterium realizmu, gdyż pozwala lepiej igłębiej spojrzeć na wychowanie (wsparcie w procesie doskonalenia się osoby).

6. Warto (należy) rozważyć wpływ (pozytywny i negatywny) na osobę i proces wychowania „rzeczy nierealnych”, a więc: planów na przyszłość, marzeń, fantazji, błędnych mniemań, słusznych/błędnych upodobań i uprzedzeń.

7. Warto (należy) rozważyć, co w aspekcie pedagogicznym miałby znaczyć postulat, aby „pokochać rzeczywistość”, „pokochać prawdę”; wydaje się, że chodzi tu o coś więcej niż tylko intelektualne uznanie stanu rzeczy, otwarcie na prawdę. Analogicznie trzeba byłoby rozważyć, jak kształtować postawę odrzucenia, „wstrętu” do złudy, mrzonek czy fikcji, które miałyby zastępować czy przeciwstawiać się rzeczywistości.

8. Warto (należy) rozważyć kwestię „bezinteresownego zaangażowania” czy „zaangażowania w bezinteresowność”, a więc takiej postawy podmiotu, która wyjaśnia bezinteresowność poznania czy działania.

Streszczenie: Artykuł prezentuje refleksje na temat postawy realistycznej $\mathrm{w}$ pedagogii. Główne tezy są następujące: 1 . Realizm jako stanowisko filozoficzne nie jest celem pedagogii (pedagogiki), lecz warunkiem podstawowym. 2. Postawa realistyczna oznacza również akceptację subiektywności człowieka. 3. Subiektywność oznacza, po pierwsze, sferę wrażeń i uczuć, po drugie, sferę świadomości i aktów poznawczych, po trzecie, i to jest najważniejsze, sferę duchowości człowieka: akty intelektu i woli. 4. Kategoria prawdy jest bardziej efektywna i głębsza w pedagogii niż kategoria realizmu. 5. Temat ten niesie ze sobą wiele interesujących i ważnych kwestii takich jak: znaczenie „rzeczy nierealnych” dla wychowania (takich jak projekty na przyszłość, marzenia, fantazje) czy kwestia „bezinteresownego zaangażowania”.

Słow a klu c zowe: postawa realistyczna, prawda, subiektywność, wzór, personalizm 


\section{Bibliografia}

Kunowski, Stefan. Podstawy współczesnej pedagogiki. Warszawa: Wydawnictwo Salezjańskie, 2000.

Mały Stownik terminów i pojęć filozoficznych. oprac. Antoni Podsiad, Zbigniew Więckowski. Warszawa: Instytut Wydawniczy Pax, 1983.

Starnawski, Witold. Prawda jako zasada wychowania. Warszawa: Wydawnictwo UKSW, 2008.

Tatarkiewicz, Władysław. O doskonałości. Warszawa: PWN, 1976.

Wojtyła, Karol. „Osoba i czyn”. W: Osoba i czyn oraz inne studia antropologiczne. Lublin: TN KUL, 1994.

Wojtyła, Karol. „Podmiotowość i «to co nieredukowalne» w człowieku”. W: Osoba i czyn oraz inne studia antropologiczne. Lublin: TN KUL, 1994.

Wojtyła, Karol. Ocena możliwości zbudowania etyki chrześcijańskiej przy zatożeniach systemu Maksa Schelera. Lublin: TN KUL, 1959. 